\title{
Influence of Organizational Culture on Strategic Involvement of Middle Level Managers in Public Forest Sector in Kenya
}

\author{
Julius O. Olayo ${ }^{1}$, George K. Mwangi ${ }^{1} \&$ Alice N. Simuyu ${ }^{2}$ \\ ${ }^{1}$ Department of Human Resource Management, Jomo Kenyatta University of Agriculture and Technology, Kenya \\ ${ }^{2}$ Department of Human Resource Management, Karatina University, Kenya \\ Correspondence: Julius O. Olayo, Department of Human Resource Management, Jomo Kenyatta University of \\ Agriculture and Technology, Kenya. Tel: 254-725-895-824. E-mail: juliusolayo@yahoo.com
}

\author{
Received: February 9, 2015 Accepted: March 5, 2015 Online Published: May 31, 2015 \\ doi:10.5539/jms.v5n2p84 URL: http://dx.doi.org/10.5539/jms.v5n2p84
}

\begin{abstract}
This study sought to explore the organizational culture and its impact on management in the context of Public Forest Sector institution in Kenya. It particularly considered the extent to which organizational culture influence strategic involvement of middle levels managers. The study was carried out using descriptive survey due to the levels of objectivity required and the ease to make comparisons between the effects of organizational culture on strategic involvement of middle level managers in the Public Forest Sector. Using quantitative data was necessary to determine whether any statistical relationship exist between the organizational culture profile and the involvement in the strategy process by middle level managers in the research organization. The targeted population was the middle level managers based at the organization's headquarter and field offices. Stratified random sampling was used to obtain a sample proportional to $10 \%$ of the population. Culture rating was found to be very accommodative to the employees. Furthermore, management is advised to find ways of encouraging team work and also incorporate and involve the employees in decision making to enhance the organizational culture of the institution. It has also been recommended that employees should be allowed to give feedback on management issues as part of fostering growth of culture. The study revealed that the management has maintained a good working environment by consistently giving opportunities to the employees to make their contribution with regard to decision making. Communication between workers and their immediate supervisors has also been found out to be good. In turn, this could lead to better output from employees.
\end{abstract}

\section{Introduction}

Culture is viewed by the contemporary authors as complex organizational phenomena (Schein, 1990; Kotter \& Heskett 1992) that is formed as a continuous sequence (Denison \& Mishra, 1995). However, the appropriateness of culture and its application in organizations was questioned by Willmot (1993) who argues that culture may simply be another means of exerting control on organizational members. Richard and Bagozzi (2003), acknowledges that internal orientation of employees is based primarily on the culture, beliefs, ethics and assumptions of the organizational staff, and therefore has the potential to be one of the most powerful influences on strategic management. There is a need for middle level Managers in Public Forest Sector in Kenya to gain understanding of the organizational culture existing in such an institution. Their involvement in strategy development may be important in gaining this understanding. The impacts of organizational culture on strategic involvement of middle managers have not been established (Carney, 2004).

The Kenyan government has undertaken reforms to revitalize the forest sector (Sessional Paper No. 4 of 2006 on Forest Policy). These reforms will provide for participation of other stakeholders including private sector and communities in the management and conservation of forests. The emerging scenario will require that the sector strategically involve its middle managers who form the bulk of the technical staff in the Headquarter and field offices to realign itself to the new cultural dimension to meet the public expectations in line with its strategies (Kenya Forest Service Strategic Plan 2009-2013). According to Pascales and Athes (1981) organizational culture is perhaps the single most powerful force for cohesion in modern organization. Managers can influence the way cultures evolves positioning their organization for a sustained competitive advantage which cannot be easily copied by competitors. Every working person instinctively knows that organizational culture is and that it drives a common way of doing things amongst colleagues, even if the way is sometimes implicit or unspoken. The 
ways of doing things can make the difference in successful organizations. Other authors argue that culture is the connective tissue that knits together an organizations people so that they can succeed in the face of challenges (Quy, 2002; Sorensen, 2002).

According to Bernar-Arogyaswamy (1987), many researchers emphasize that culture is an asset and that a large number of functions in the organization can be attributed to organizational culture. Hofstede (1990) suggests that the culture of an organization defines appropriate behavior and bonds, motivates individuals and asserts solutions where there is ambiguity. However, some authors such as Sathe (1985) argue that an organizations culture can also be a liability. This is because shared beliefs, values and assumptions can interfere with the needs of the business and lead people to think and act in inappropriate ways.

Responsiveness to the organizational leadership desire is based on the level of involvement of middle managers in the strategic process for competitive advantage of the organization. Kotter and Heskett (1992) highlights that the ability to adapt may be dependent on the culture itself and cultures that are bureaucratic, risk-averse and reactive are likely to be less responsive on the other hand, adaptive cultures involve risk-taking, trusting and a proactive approach to individual and organizational life. Members actively support one another's effort to identify all problems and implement workable strategies (Harris, 2000).

The various researchers have recognized the strategic role of middle level managers in the profit organizations (Burgleman, 1983, Floyd \& Wooldridge, 1996, Dutton et al., 1997). Research has not indicated the middle managers role is not for profit organizations in public forest sector institutions or the effects of organizational culture on middle managers strategic involvement in such institutions. This relationship to explore to what extent the organizational culture influences strategic involvement of middle managers in public forest sector in Kenya is the concern of this study.

Insights into various aspects of organizational culture will contribute to theory building, while the findings will help practitioners to assess the management of the organizations at its middle managers in not for profit organizations. This will in turn help practitioners to design and implement quality strategic involvement programmes in organizations faced with cultural change to enhance organizational performance. Likewise the research will serve as a building block for future research on effects of organizational culture on strategic involvement of managers, similarly in practical value, the research will lend support to the important role of organizational culture plays in organizational performance. The study aims to determine the influences of organizational culture on strategic involvement of middle managers in public forest sector institution in Kenya.

\section{Methodology}

\subsection{Research Design}

The study was carried out using descriptive survey due to the levels of objectivity required for this research and the ease to make comparisons between the effects of organizational culture on strategic involvement of middle managers in the Public Forest Sector. Using quantitative data was necessary to determine whether any statistical relationship exist between the organizational culture profile and the involvement in the strategy process by middle managers in the research organization.

\subsubsection{Target Population}

The population of interest was the middle managers based at the various research organizations headquarter offices and field offices classified to be in employment grades (KFS 7, 6 and 5).

\subsubsection{Sample Design}

According to Mugenda and Mugenda, (2003) for descriptive studies, a ten percent (10\%) of the population is enough a sample to represent the different characteristics of the population. Stratified random sampling was used to obtain a sample proportional to $10 \%$ of the population. By use of staff payroll a simple random sampling was done to select staff who participated in the study.

\subsubsection{Data Collection Techniques}

A simple structured questionnaire designed incorporating the various aspects of organizational culture based on Denison model (Denison, 1990) cultural assessment tool was used to collect desired information. The secondary data was obtained from the organizations decision records from management actionable points, informal interviews and observation of top management behavior and delegation of tasks will be done in formal and informal forums by the researcher to validate data obtain from the primary sources. 


\subsection{Data Analysis}

Descriptive and quantitative techniques were used to analyze the data. Chi square test of independence of the different data sets was performed to test data association and establish the different relationships that are inherent in the data collected. Descriptive methods such as frequency distribution tables, were produced in the data analysis process which displayed the complex relationships that exit in the datasets using a software environment referred to as Statistical package for social sciences (SPSS).

\section{Data Analysis and Presentation of Results}

From the analysis on respondent characteristics it is shown that majority of the employees of Kenya forest service are aged above 41 years (Figure 1). It is worth to note that nobody aged less than 25 years was employed (Table 1). This can be attributed to possibility of policy not allowing employment of underage persons. Nonetheless, there are a very small percentage of those who were aged between 36-40 years of age.

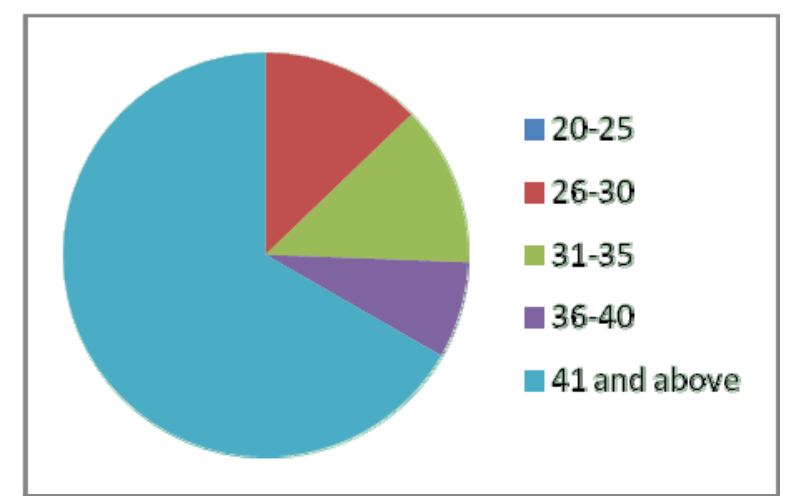

Figure 1. Percentage of respondents based on age

The study revealed that the forestry service is dominated by male employees at $84.6 \%$. Females only counted to $15.4 \%$ of the total count. It is also important to mention that $87 \%$ of responses were married though $10 \%$ were single. Majority of employees, that is $66 \%$, belonged to employment grade KF -5 while the least number belonged to employment grade KFS -6 and KFS -7 had $21 \%$ which was slightly bigger than KFS -6 . The study also sought to find out how long the workers have worked in the forest sector. It was noted that $67 \%$ were counted to have worked for over 3 years in the organization implying that the forest service retains employees for a long time. $23 \%$ have worked between 2 and 3 years in the organization (Table 1). A small percentage has worked for either 1 year or less than 1 year (Table 1). The study also revealed that more than half of the respondents had undergraduate degree as their highest qualification (Table 1).

Table 1. Characteristics of the respondents sampled

\begin{tabular}{lll}
\hline Characteristic & Response & Percentage \\
\hline Marital status of participant & Married & $87.2 \%$ \\
& Single & $10.3 \%$ \\
Employment grades & Others & $2.6 \%$ \\
& KFS 5 & $65.8 \%$ \\
Length of service in the forest sector & KFS 6 & $13.2 \%$ \\
& KFS 7 & $21.1 \%$ \\
& 1 year and below & $10.3 \%$ \\
Education level attained & $2-3$ years & $23.1 \%$ \\
& Over 3 years & $66.7 \%$ \\
& Postgraduate degree & $38.5 \%$ \\
& Degree & $51.3 \%$ \\
\hline
\end{tabular}

Source: Author (2009). 
Organizational culture describes the psychology, attitudes, experiences, beliefs and values (personal and cultural values) of an organization. It has been defined as the specific collection of values and norms that are shared by people and groups in an organization and that control the way they interact with each other and with stakeholders outside the organization. This specific objective aimed at finding out the relationships that interacts to shape up the organizational culture of the forest sector institution in Kenya. The analysis below summarizes the different aspects of organizational culture and how it affects strategic involvement of middle managers in the institution. The results indicate that the majority of the workers are field officers (Figure 2). On how one would rate the culture of their organization, majority of the respondents felt that it is accommodative while the least members felt that the culture is hostile or just felt otherwise (Figure 3).

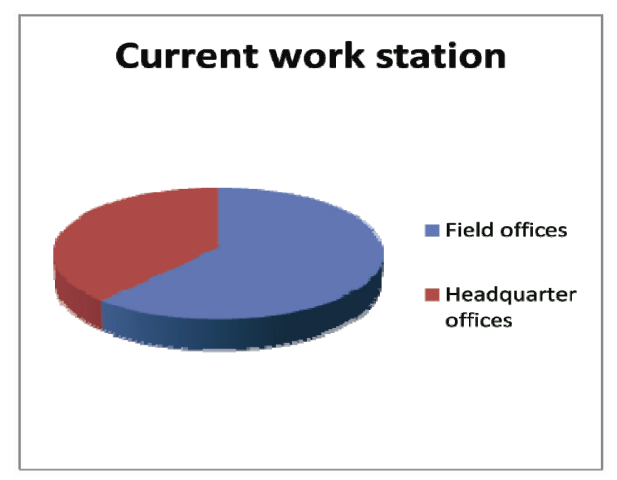

Figure 2. The current station of the workers

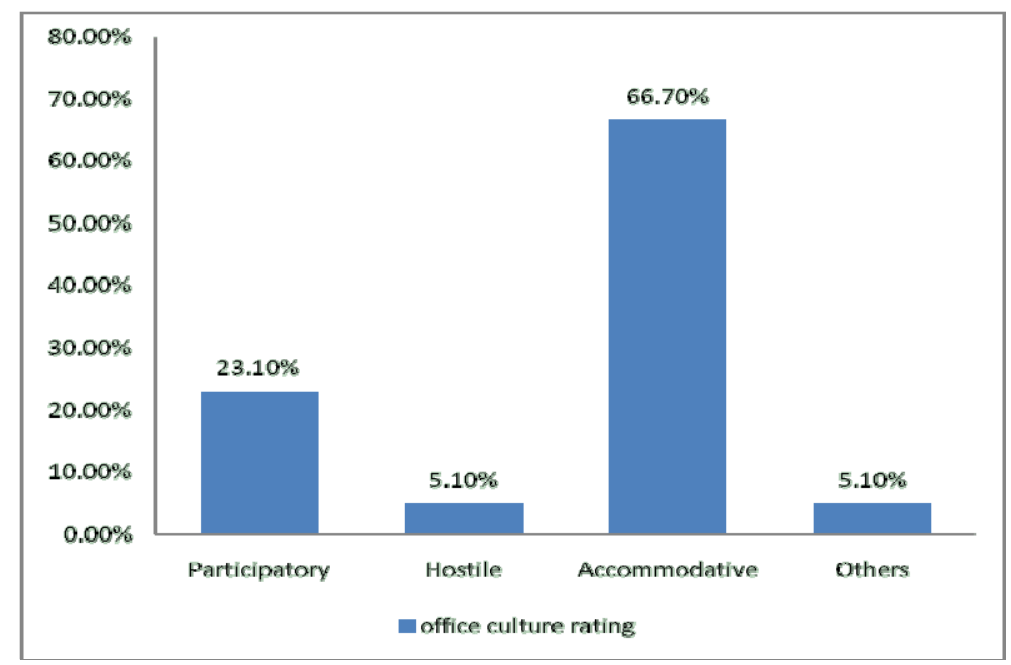

Figure 3. The office culture rating

In order for the organization to enhance its culture, most workers felt that the organization should encourage team work within members and employees should be involved in decision making (Figure 4). Some felt that giving feedback is important in enhancing culture of an organization (Figure 4). It is also worth to note that the mission of the organization supports the organization culture. This can be seen from the $82 \%$ positive responses that were recorded, although $18 \%$ disagreed with the assertion that the mission of the organization supports the culture. Majority of respondents strongly felt that the culture of the organization is supportive of its values, beliefs and assumptions while the rest felt that organization culture does not support its values, beliefs and assumptions (Table 2). For those who disagreed that organization culture supports its values, beliefs and assumptions, majority of them felt that employee involvement in the processes, will improve that while the rest felt that top management support should be enhanced or the organization should review its mission and vision (Table 2). 


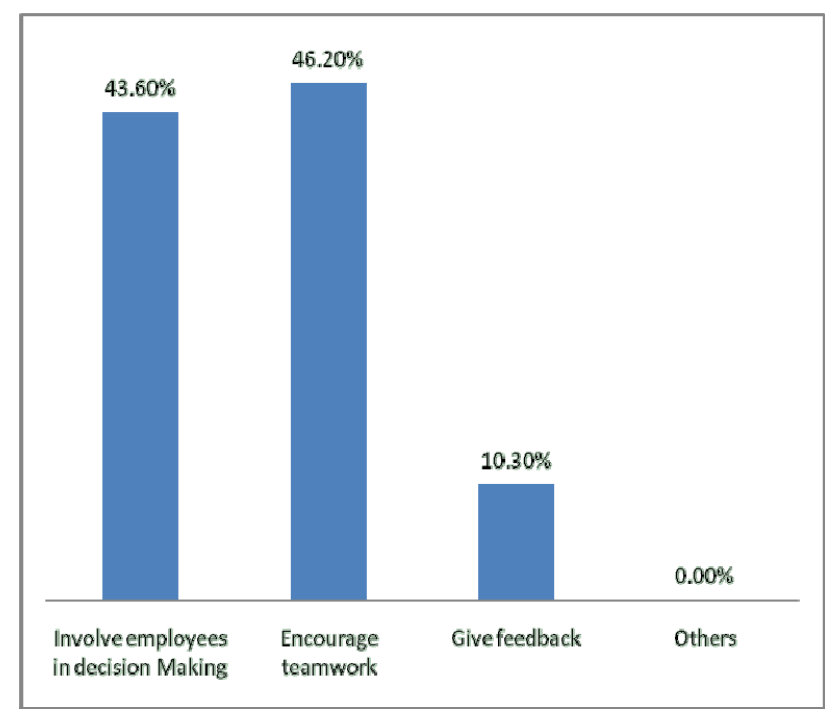

Figure 4. What organization should do to enhance its culture

Table 2. Whether organizational culture is supportive to its values and what should be done to improve it

\begin{tabular}{|c|c|c|}
\hline Characteristics & Response & Percentage \\
\hline \multirow[t]{3}{*}{ Organizational culture supportive of its values, belief and assumptions } & Yes & $61.5 \%$ \\
\hline & No & $35.9 \%$ \\
\hline & (Missing) & $2.6 \%$ \\
\hline \multirow[t]{4}{*}{ what does one consider should be done to improve this } & Employee involvement & $60.0 \%$ \\
\hline & Review its mission and vision & $13.3 \%$ \\
\hline & Top management support & $26.7 \%$ \\
\hline & Others & $.0 \%$ \\
\hline
\end{tabular}

Source: Author (2009).

The chi square values indicate that there is enough evidence from the data to support the fact that the organizational culture influences strategic involvement of middle managers in the forest sector (Table 3). The office culture rating has been found to be very accommodative to the employees (Table 3). Since the value of computed chi is greater than that of the tabulated, this suggests that there is sufficient information to conclude so. It is also supported by the fact that the mission and vision of the organization are quite significant in influencing the culture of middle managers in the sector. Furthermore, it can also be seen that the culture of the organization is supportive of its values, belief and assumptions (Table 3).

Table 3. How organization culture influences involvement of middle managers strategic management in forest sector in Kenya

\begin{tabular}{llll}
\hline & Chi-Square & d.f. & $P$-value \\
\hline Current work station & $2.077^{\mathrm{a}}$ & 1 & 0.150 \\
Office culture rating & $39.462^{\mathrm{b}}$ & 3 & 0.000 \\
What organization should do to enhance its culture & $9.385^{\mathrm{c}}$ & 2 & 0.009 \\
Mission of organization supports organization culture & $16.026^{\mathrm{a}}$ & 1 & 0.000 \\
Organizational culture supportive of its values, belief and assumptions & $20.462^{\mathrm{c}}$ & 2 & 0.000 \\
If no (to above) what does one consider should be done to improve this & $5.200^{\mathrm{d}}$ & 2 & 0.074 \\
\hline
\end{tabular}

Source: Author (2009).

On the particular specific objective on whether organizational culture factors affects the strategic involvement of middle managers in public forest sector institution in Kenya, the question which sought to establish how the employees could assess communication between them and their immediate supervisors, majority of them 
indicated that they had open communication while only a small percentage indicated that they had rigid communication with their supervisors (Figure 5). On the other question which was to find out whether managers/immediate supervisors held frequent personal discussion sessions regarding workplace issues, majority agreed (Figure 6). With such impressive responses, then the study also sought to assess the evaluation of employee performance in recent past by their immediate supervisors, $90 \%$ of responses showed that the evaluation process was objective while either 5\% thought that the evaluation was biased or had varied opinion about it (Table 4). This is seen in long run has affected the output of employees in the organization from the $82 \%$ responses that agreed with this. $18 \%$ felt that this did not affect their output on duty (Table 4 ).

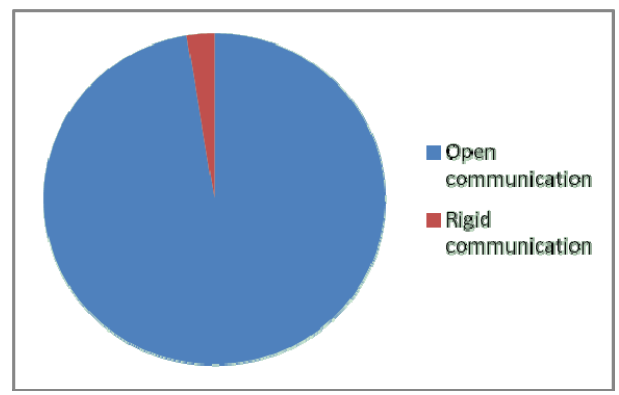

Figure 5. Respondents feeling on the level of communication with their supervisors

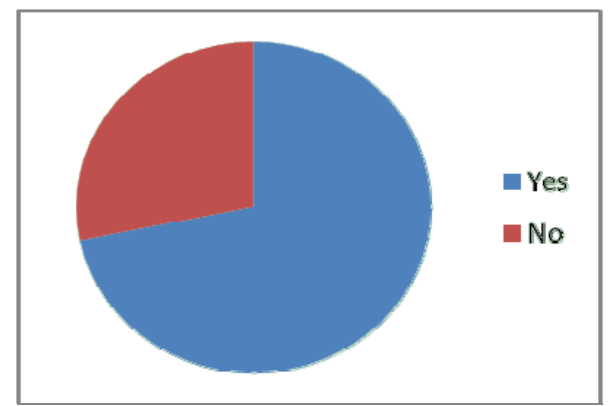

Figure 6. Respondents feeling on whether supervisors hold frequent personal discussion sessions with them regarding workplace issues

Table 4. Some organizational culture factors that influence strategic involvement of middle managers in management

\begin{tabular}{lll}
\hline Characteristics & Response & Percentage \\
\hline How would you assess the evaluation of your performance in the recent past by your & Objective & $89.7 \%$ \\
immediate supervisor? & Biased & $5.1 \%$ \\
& Others & $5.1 \%$ \\
Has this affected your output in the organization? & Yes & $82.1 \%$ \\
& No & $17.9 \%$ \\
\hline
\end{tabular}

Source: Author (2009).

The chi square values indicate that most of the variables of interest to the specific objective were statistically significant since at a $0.5 \%$ level of significance (Table 5). The only question that was not significant is the question that aimed at finding out whether managers/immediate supervisors hold frequent personal discussion sessions regarding work place issues. This implies then that the meeting sessions are held purely by chance and such cases issues regarding the workplace not discussed. Hence it can suggested that the study has enough evidence to conclude that when there is communication between employees and their immediate supervisors, then the evaluation done by immediate supervisors to their employees is highly appreciated and consequently affects the output in the organization. 
Table 5. Chi square values of different aspects of organizational culture and its influence to management

\begin{tabular}{|c|c|c|c|}
\hline & Chi-Square & d.f. & $P$-value \\
\hline $\begin{array}{l}\text { How would you assess communication between you and your immediate } \\
\text { supervisor? }\end{array}$ & $35.103^{\mathrm{a}}$ & 1 & 0.000 \\
\hline $\begin{array}{l}\text { Do managers/immediate supervisors hold frequent personal discussions } \\
\text { sessions with you regarding workplace issues? }\end{array}$ & $7.410^{\mathrm{a}}$ & 1 & 0.006 \\
\hline $\begin{array}{l}\text { How would you assess the evaluation of your performance in the recent past by } \\
\text { your immediate supervisor? }\end{array}$ & $55.846^{\mathrm{b}}$ & 2 & 0.000 \\
\hline Has this affected your output in the organization? & $16.026^{\mathrm{a}}$ & 1 & 0.000 \\
\hline
\end{tabular}

Source: Author (2009).

\section{Conclusions and Recommendation}

The concept of organizational culture has drawn attention to the long-neglected, subjective or 'soft' side of organizational life. However, many aspects of organizational culture have not received much attention. Instead, emphasis has been placed primarily on the cultural and symbolic aspects that are relevant in an instrumental/pragmatic context. From the results of this study culture rating has been found to be very accommodative to the employees. In parts where the employees felt that the culture did take care of their needs, the management is advised to find ways of encouraging team work and also incorporate and involve the employees in decision making to enhance the organizational culture of the institution. In other situations, the employees should be allowed to give feedback.

\section{Acknowledgements}

The authors are grateful to the respondents for providing the information required in this research. The managers of the various institutions who allowed data for this study to be obtained are also acknowledged.

\section{Reference}

Bernar-Arogyaswamy, C. M. B. (1987). Organization Culture: internal \& external fits. Journal of Management, 13, 647-659. http://dx.doi.org/10.1177/014920638701300406

Burgelman R. A. A. (1983). Model of the interaction of strategic behavior, corporate Context and the concept of strategy. Academy of management Review, 8(1), 61-70.

Carney, M. (2004). Middle manager involvement in strategy development in not - for - Profit organizations; the direction of nursing perspective-how organizational Structure impacts on the role. Journal of Nursing Management, 12, 13-21.

Denison, D. (1990). Corporate Culture and organizational effectiveness. New York: John Wiley.

Denison, D. R., \& Mishra A. K. (1995). Toward a theory of organizational culture and effectiveness. Organization Science, 6(2), 204-223. http://dx.doi.org/10.1287/orsc.6.2.204

Dutton J. E., Ashford S. J., O’Nell, R. M., Hayes, E., \& Wierba, E. E. (1997). Reading the Wind: How middle managers read the context for issue selling. Strategic Management Journal, 18(5), 407-425.

Floyd, S. W., \& Wooldridge, B. (1996). The strategic middle managers: How to create and sustain competitive advantage. San Franscisco, CA, USA: Jossey-bass.

Harris, E. O. A. L. (2000). Leadership style, organization culture, and performance: empirical evidence from UK companies. The International Journal of Human Resource Management, 11, 766-788. http://dx.doi.org/10.1080/09585190050075114

Hofstede, G. (1990). Measuring organizational culture: A qualitative \& quantitative study across twenty cases. Administrative Science Quarterly, 35, 286-317. http://dx.doi.org/10.2307/2393392

Kenya Forest Service Strategic Plan. (2009-2013). Nairobi, Kenya.

Kenya Forestry Master Plan. (February, 1994).

Kotter, J. P., \& Hekett, J. L. (1992). Corporate culture and performance. New York: Free Press.

Mugenda, O. M., \& Mugenda, A. G. (2003). Research methods: Quantitative and qualitative approaches. Nairobi ACT Press.

Pascale, R. T., \& Athes, A. G. (1981). The art of Japanese Management: Applications for American Executives. 
New York, USA: Simon and Schuster.

Quy, H. (2002). Motional balancing of organizational continuity and radical change. Administrative science quarterly.

Richard, Jr., P., \& Bagozzi, W. V. J. C. (2003). Culture Moderates the Self-Regulation of Shame and Its Effects on Performance. Journal of Applied Psychology, $219-233$. http://dx.doi.org/10.1037/0021-9010.88.2.219

Sathe, V. (1985). Culture and related corporate realities. Homewood, IL: Richard D. Ivwin.

Schein, E. H. (1990). Organizational culture. The American Psychologists, 45(2), 109-119. http://dx.doi.10.1037/0003-066x.45.2.109

Sorensen, J. B. (2002). The strength of corporate culture and the reliability of firm performance. Administrative Science Quarterly, 70-91. http://dx.doi.org/10.2307/3094891

Wilmott, H. (1993). Strength is ignorance; slavery is freedom. Managing culture in modern organizations. Journal of Management Studies, 30(4), 515-552.

\section{Copyrights}

Copyright for this article is retained by the author(s), with first publication rights granted to the journal.

This is an open-access article distributed under the terms and conditions of the Creative Commons Attribution license (http://creativecommons.org/licenses/by/3.0/). 